\title{
PENGARUH MODEL PEMBELAJARAN BERDASARKAN MASALAH TERHADAP HASIL BELAJAR FISIKA SISWA PADA MATERI POKOK LISTRIK DINAMIS DI SMA NEGERI 13 MEDAN T.P 2014/ 2015
}

\author{
Dortia Melva Epryza Sinaga dan Henok Siagian \\ Jurusan Fisika FMIPA Universitas Negeri Medan \\ dortia_sinaga@yahoo.com
}

\begin{abstract}
ABSTRAK
Penelitian ini bertujuan untuk mengetahui pengaruh model pembelajaran berdasarkan masalah terhadap hasil belajar siswa pada materi pokok Listrik Dinamis di kelas X SMANegeri 13 Medan T.P 2014/2015.Jenis penelitian ini adalah quasi eksperimendenganpopulasiseluruh siswa kelas X SMANegeri 13 Medan T.P 2014/2015 yang terdiri dari 10 kelas. Pengambilan sampel dilakukan dengan cara cluster random sampling dengan mengambil 2 kelas yaitu kelas $\mathrm{X}$ MIA 2 sebagai kelas eksperimen dan kelas X-MIA 3 sebagai kelas kontrol. Instrumen yang digunakan adalah tes hasil belajar berbentuk essay test dengan jumlah 10 soal. Hasil penelitian diperoleh nilai rata-rata pretes kelas eksperimen 36,7 dan kelas kontrol 35,1. Dari uji normalitas dan uji homogenitas diperoleh bahwadata pretes kedua kelas sampel normal dan homogen. Setelahdiberi perlakuan berbeda, yaitu model pembelajaran berdasarkan masalahpada kelas eksperimen dan pembelajaran konvensional pada kelas kontrol maka diperoleh nilai rata-rata postes kelas eksperimen 48,1dan kelas kontrol 42,1. Hasil uji hipotesis diperoleh $t_{\text {hitung }}>t_{\text {tabel}}$, dapat disimpulkan bahwa adapengaruh model pembelajaran berdasarkan masalahterhadap hasil belajar siswa pada materi pokok Listrik Dinamis di kelas X semester II SMA Negeri 13 Medan T.P $2014 / 2015$.
\end{abstract}

Kata kunci:model pembelajaran berdasarkan masalah, hasil belajar, fisika.

\section{ABSTRACT}

This research aimed toknow the effect of problem based learning model onstudents' learning outcomes in the subject matterdynamic electricinclass X SMA Negeri 13 Medan A.Y. 2014/2015.The type ofresearch was quasi-experimentalwith the population were the tenth grade students ofSMA Negeri 13 Medan A.Y. 2014/2015 consisting of 10 classes. Samples were taken 2 classes determined bycluster random sampling technique, the class X-MIA 2 as experiment class and class $X^{-}$ MIA 3 as control class. The instruments usedin the form of essay as much as10 questions. The research result shows the pretest's average score of experiment class is 36,7and control class is 35,1. From normality test and homogenity test obtained that pretest of experiment class and control class is normal and homogen.After they have been given different treatment, problem based learning model for experimental class and conventional learning model for controlling classit is obtained that the posttest's average score for experiment class is 48, 1and controlling class's is 42,1. The hypothesis gettcalculate $>t_{\text {table, }}$ it can be concluded there iseffect of problem based learning model in the subject matter dynamic electric inclass X SMA Negeri 13 Medan 2014/2015.

Keywords:Problem based learning model,learning outcome, physics. 


\section{PENDAHULUAN}

Peran pendidikan sangat penting untuk menciptakan masyarakat yang cerdas, damai, terbuka dan demokratis. Keberhasilan pendidikan dipengaruhi oleh perubahan dan pembaharuan dalam segala unsur-unsur yang mendukung pendidikan antara lain siswa, guru, alat, metode, materi dan lingkungan pendidikan. Semua unsure tersebut saling terkait dalam mendukung tercapainya tujuan pendidikan.

Masalah utama dalam pembelajaranpadapendidikan formal (sekolah) dewasa ini adalah masih rendahnya daya serap peserta didik. Hal ini tampak dari nilai rata-rata hasil belajar peserta didik yang senantiasa masih memprihatinkan. Proses pembelajaran hingga dewasa ini masih mendominasi guru dan tidak memberikan akses bagi anak didik untuk berkembang secara mandiri melalui penemuan dalam proses berpikirnya (Trianto, 2011: 5). Masalah ini menjadi factor penghambat tercapainya tujuan pembelajaran yang diharapkan, seperti pada mata pelajaran fisika.

Fisika adalah cabang ilmu pengetahuan alam yang mempelajari fenomena dan gejala alam secara empiris, logis, sistematis dan rasional yang melibatkan proses dan sikap ilmiah. Fisika merupakan salah satu pelajaran yang cukup menarik karena langsung berkaitan dengan kejadian yang nyata dan juga dapat diaplikasikan dalam kehidupan seharihari. Namun kenyataannya, pelajaran fisika hingga saat ini masih dianggap sebagai pelajaran yang sulit dipahami. Hal ini terbukti dari hasil studi pendahuluan yang dilakukan di kelas $\mathrm{X}$ SMA Negeri 13 Medan pada tanggal 30 Januari 2015 dengan menyebarkan angket.

Berdasarkanhasilangketdiperoleh informasibahwa $5 \%$ dari 40 siswa menyatakan pelajaran fisika sangat mudah dipahami, 27,5\% mengatakan pelajaran fisika mudah dipahami, 62,5mengatakan bahwa pelajaran fisika sulit dipahami, 5\% mengatakan bahwa pelajaran fisika sangat sulit dipahami. Pembelajaran selama ini hanya menuntut siswa untuk menguasai materi dan menghafal rumus-rumus untuk memecahkan suatu masalah tanpa mengetahui konsep dan aplikasinya dalam kehidupan seharihari. Siswa hanya bisa menulis dan mencatat apa yang didengar dan dijelaskan oleh guru, tanpa pernah terlibat langsung dalam proses menemukan pengetahuan atau pun mengembangkan pengetahuan sesuai dengan kemampuannya sendiri.

Berdasarkan hasil wawancara dengan salah seorang guru fisika di SMA Negeri 13 Medan, diperoleh informasi bahwa respon siswa terhadap mata pelajaran fisika masih rendah. Hal ini dapat dilihat selama proses pembelajaran hanya beberapa siswa yang aktif bertanya atau mengemukakan pendapat. Model pembelajaran yang diterapkan di dalam kelas masih pembelajaran konvensional dengan metode ceramah dan metode tanya jawab. Dampaknya, hasil belajar siswa masih kurang dari KKM. Nilai rata-rata hasil belajar siswa hanya mencapai 60 sedangkan KKM mata pelajaran fisika adalah 75 .

Berdasarkan kenyataan tersebut, perlu diterapkan suatu pembelajaran yang membuat siswa terlibat dalam keseluruhan proses pembelajaran dengan mengangkat fenomena fisika yang lebih autentik dalam kehidupan seharihari.Peningkatan hasil belajar siswa didukungolehpenggunaan model pembelajaran yang bervariasi.Secara umum istilah model pembelajaranadalah suatu perencanaan atau pola yang dapat digunakan untuk mendesain pola-pola mengajar secara tatap muka di dalam kelas dan untuk menentukan material/perangkat pembelajaran termasuk didalamnya buku-buku, media (film-film), tipe-tipe, 
program-program media komputer, dan kurikulum (Ngalimun, 2014: 27).

Model

pembelajaran

berdasarkan masalah merupakan pembelajaran yang penyampaiannya dilakukan dengan cara menyajikan suatu permasalahan, mengajukan pertanyaan-pertanyaan, memfasilitasi penyelidikan dan membuka dialog dimana permasalahan yang dikaji merupakan permasalahan kontekstual yang ditemukan oleh peserta didik dalam kehidupan sehari-hari (Sani, 2014: 127). Sasaran utama kegiatan model pembelajaran berdasarkan masalah adalah memberikan kesempatan kepada siswa untuk bereksplorasi mengumpulkan dan menganalisis data secara lengkap untuk memecahkan masalah yang dihadapi. Tujuan yang ingin dicapai adalah kemampuan siswa untuk berpikir kritis, analitis, sistematis dan logis untuk menemukan alternatif pemecahan masalah melalui eksplorasi data secara empiris dalam rangka menumbuhkan sikap ilmiah (Sanjaya, 2010: 216)

Penelitian terkait tentang model pembelajaran berdasarkan masalah telah dilakukan oleh Suhanda (2014) dan diperoleh rata-rata hasil belajar di kelas eksperimen sebesar 75,13 dan dikelas kontrol sebesar 66,19. Artinya, penerapan model pembelajaran berdasarkan masalah dapat meningkatkan hasil belajar siswa. Peneliti lainnya yang meneliti tentang model pembelajaran ini adalah Setiawan (2013) diperoleh rata-rata hasil belajar siswa di kelas eksperimen sebesar 73,77, sedangkan kelas kontrol sebesar 62,76. Artinya Ada perbedaan yang signifikan hasil belajar siswa menggunakan model pembelajaran berdasarkan masalahdengan menggunakan pembelajaran konvensional pada pembelajaran fisika di SMA. Selanjutnya, Medriati (2013) dengan menerapkan model pembelajaran berdasarkan masalah diperoleh nilai rata-rata siklus I sebesar 69,91, siklus II sebesar 80,13 dan siklus III sebesar 90,32. Artinya Pembelajaran fisika dengan menerapkan model pembelajaran berdasarkan masalah dapat meningkatkan aktivitas dan hasil belajar siswa dalam pembelajaran fisika. Ketiga penelitian ini memperlihatkan bahwa ada pengaruh model pembelajaran berdasarkan masalah terhadap hasil belajar siswa.

Penelitian ini masih mengalami beberapa kendalaantara lainkurang terlibatnya siswa pada saat proses pembelajaran berlangsung hingga menyebabkan sulitnya mengatur alokasi waktu, kurangnya penalaran siswa dalam menemukan masalah. Peneliti ingin mengadakan pembelajaran berdasarkan masalah dengan tujuan untuk meningkatkan upaya-upaya yang telah diteliti oleh peneliti sebelumnya.

Adapun tujuan penelitian adalah untuk mengetahui pengaruh model pembelajaran berdasarkan masalah terhadap hasil belajar siswa pada materi pokok listrik dinamis di kelas $\mathrm{X}$ semester II SMA Negeri 13 Medan T.P. $2014 / 2015$.

\section{METODE PENELITIAN}

Populasi dalam penelitian ini adalah seluruh siswa kelas X SMA Negeri 13 Medan T.P 2014/2015 yang terdiri dari 10 kelas dengan jumlah siswa 400 orang. Pada penelitian ini sampel terdiri dari dua kelas yang dipilih secara acak dengan teknik Cluster Random Sampling yaitu kelas XMIA-2 sebagai kelas eksperimen (kelas yang diajar menggunakan model pembelajaran berdasarkan masalah) dengan jumlah 35 siswa dan kelas XMIA-3 sebagai kelas kontrol (kelas yang diajar menggunakan model pembelajaran konvensional) dengan jumlah 34 siswa.Penelitian ini termasuk jenis penelitian quasi eksperimen yaitu merupakan penelitian yang dimaksudkan untuk mengetahui ada atau tidaknya akibat dari sesuatu 
yang dikenakan pada subjek yaitu siswa. Desain penelitian yang digunakan adalah "Two Group Pre Test-Post Test Design".

Alat bantu yang digunakan dalam penelitian ini adalah tes hasil belajar berbentuk tes essay dengan jumlah 10 item yang sudah divalidasikan. Tes ini digunakan untuk mengetahui hasil belajar siswa sebelum dan sesudah pembelajaran yang diberi perlakuan berupa model pembelajaran berdasarkan masalah maupun yang tidak diberi perlakuan model pembelajaran berdasarkan masalah.

Sebelum

dilakukan

penganalisisan data, terlebih dahulu ditentukan skor masing-masing kelompok sampel lalu dilakukan pengolahan data dengan langkahlangkah sebagai berikut:

a) Menghitung nilai rata-rata dan simpangan baku

b) Uji normalitas dengan menggunakan ujililliefors

c) Uji homogenitas dengan menggunakan uji kesamaan dua varians

Uji normalitas dan uji homogenitas dimaksudkan sebagai prasyarat melakukan uji hipotesis jika populasi terdistribusi normal dan homogen.

d) Pengujian hipotesis dengan menggunakan uji t

Uji t dua pihak digunakan untuk mengetahui kesamaan kemampuan awal siswa pada kedua kelompok sampeldan uji hipotesis satu pihak digunakan untuk mengetahui pengaruh dari suatu perlakuan yaitu model pembelajaran berdasarkan masalah terhadap hasil belajar siswa.

\section{HASIL DAN PEMBAHASAN HasilPenelitian}

Adapun hasil penelitian ini adalah bahwa nilai rata-rata pretes kelas eksperimen sebesar 36,1 dan nilai rata-rata pretes kelas kontrol sebesar 35,1 seperti yang ditunjukkan pada gambar 1.

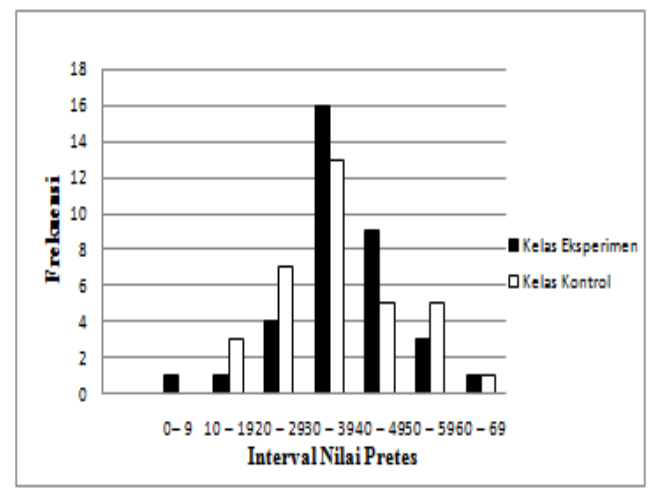

Gambar1 Diagram Batang Data Pretes Kelas Eksperimen dan Kelas Kontrol

Hasil uji normalitas data pretes pada kedua kelas masing-masing diperoleh $\mathrm{L}_{\text {hitung }}=0,0848<\mathrm{L}_{\text {tabel }}=$ 0,1498 dan Lhitung $=0,1016<$ Ltabel $^{=}$ 0,1519 . Hasiluji homogenitas pada data pretes diperoleh $\mathrm{F}_{\text {hitung }}=1,06<\mathrm{F}_{\text {tabel }}=$ 1,76. Berdasarkan hasil kedua pengujian ini disimpulkan bahwa populasi berdistribusi normal dan homogen sehingga layak dilakukan uji hipotesis dua pihak dengan hasil uji hipotesis seperti pada Tabel 2.

Tabel 2.Uji Hipotesis Data Pretes

\begin{tabular}{clcccc}
\hline No & Data Kelas & $\begin{array}{c}\text { Rata- } \\
\text { rata }\end{array}$ & t $_{\text {hitung }}$ & $\mathbf{t}_{\text {tabel }}$ & $\begin{array}{c}\text { Kesimp } \\
\text { ulan }\end{array}$ \\
\cline { 1 - 2 } 1. & $\begin{array}{l}\text { Kelas } \\
\text { eskperimen }\end{array}$ & 36,7 & & & \\
\cline { 1 - 2 } 2. & $\begin{array}{l}\text { Kelas } \\
\text { kontrol }\end{array}$ & 35,1 & 0,54 & 1,99 & $\begin{array}{c}\text { Ho } \\
\text { diterima }\end{array}$ \\
\hline
\end{tabular}

Selama kegiatan proses pembelajaran dilakukan tiga kali pertemuan diperoleh bahwa hasil belajar siswa di kelas eksperimen yang menerima pembelajaran dengan model pembelajaran berdasarkan masalah mengalamipeningkatan. $\mathrm{Hal}$ initerlihatdari LKS yang dibagikan kepada siswa. Pada pertemuan I diperoleh nilai rata-rata LKS siswa48,6, pada pertemuan II diperoleh nilai ratarata LKS 60,4 danpadapertemuan III diperolehnilai rata-rata LKS siswa 77,8.

Perolehan nilai rata-rata postes setelah diberikan perlakuan pembelajaran dengan model pembelajaran berdasarkan masalah pada kelas eksperimen sebesar 48,1 dan 
pembelajaran konvensional pada kelas kontrol sebesar 42,1seperti yang ditunjukkan pada Gambar2.

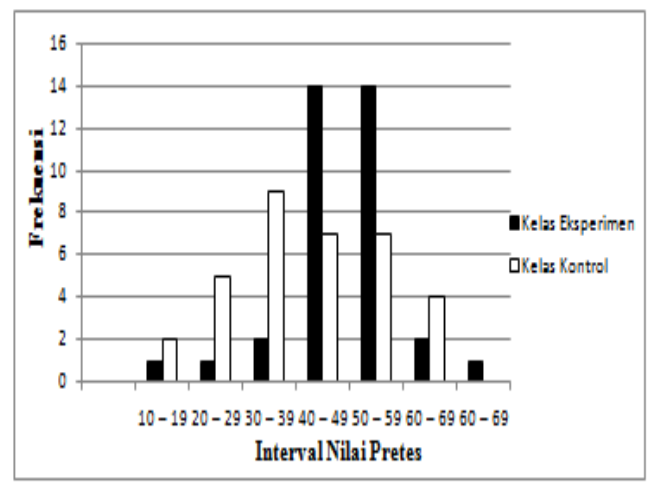

Gambar2 Diagram Batang Data Postes Kelas Eksperimen dan Kelas Kontrol

Hasil uji normalitas data postes pada kedua kelas masing-masing diperoleh $\mathrm{L}_{\text {hitung }}=0,1120<\mathrm{L}_{\text {tabel }}=$ 0,1498dan $\mathrm{L}_{\text {hitung }}=0,1033<\mathrm{L}_{\text {tabel }}=$ 0,1519 .Hasiluji homogenitas pada data postes diperoleh $\mathrm{F}_{\text {hitung }}=1,43<\mathrm{F}_{\text {tabel }}=$ 1,76. Berdasarkan hasil kedua pengujian ini disimpulkan bahwa populasi berdistribusi normal dan homogen sehingga layak dilakukan uji hipotesis satu pihak dengan hasil uji hipotesis seperti pada Tabel 4.

Tabel 4. Uji Hipotesis Data Postes

\begin{tabular}{llllc}
\hline No Data Kelas & $\begin{array}{c}\text { Nilai } \\
\text { Rata- } \\
\text { rata }\end{array}$ & thitung $^{\text {tatabel }}$ & $\begin{array}{c}\text { Kesimp } \\
\text { ulan }\end{array}$ \\
\hline 1. & $\begin{array}{l}\text { Kelas } \\
\text { eskperimen }\end{array}$ & 48,1 & & \\
\cline { 1 - 2 } 2. & $\begin{array}{l}\text { Kelas } \\
\text { kontrol }\end{array}$ & 42,928 & 1,667 & $\begin{array}{c}\mathrm{H}_{\mathrm{a}} \\
\text { diterima }\end{array}$ \\
\hline
\end{tabular}

\section{Pembahasan}

Nilai rata-rata pretes siswa di kelas kontrol sebesar 35,1 dan nilai rata-rata postes sebesar 42,1 sedangkan di kelas eksperimen nilai rata-rata pretesnya 36,7 dan nilai rata-rata postesnya 48,1. Hasil penelitian menunjukkan bahwa ada pengaruh model pembelajaran berdasarkan masalah terhadap hasil belajar siswa pada materi pokok Listrik Dinamis di Kelas X MIA Semester II SMA Negeri 13 Medan.
Pembelajaran dikatakan berhasil jika $75 \%$ dari seluruh jumlah siswa mencapai nilai ketuntasan. Seorang siswa disebut telah tuntas dalam belajar, bila siswa telah $75 \%$ menguasai kompetensi atau sekurang-kurangnya mencapai skor minimal 75. Spesifikasi tes hasil belajar saat dilakukan pretes di dua kelas diperoleh bahwa soal dengan kategori C4, C5 dan C6 belum mencapai nilai $75 \%$. Soal nomor 1,2 dan 3 dengan kategori $\mathrm{C} 4$ mencapai nilai 49\%. Soal 4,5,6 dan 7 dengan kategori C5 mencapai nilai 44\%. Soal 8,9 dan 10 dengan kategori C6 mencapai nilai 52\%. Berdasarkan nilai KKM mata pelajaran fisika di sekolah tempat peneliti melakukan penelitian, hasil belajar siswa secara klasikal dikatakan belum tuntas. Hal ini disebabkan oleh beberapa faktor yang dialami peneliti di kelas yaitu ketersediaan alat dan bahan yang terbatas dan keterbatasan waktu saat pembelajaran, sehingga proses pembelajaran kurang maksimal.

Siswa yang mampu mencapai KKM di kelas eksperimen hanya 3\% dengan nilai terendah 15 dan nilai tertinggi 75 , sementara di kelas control tidak ada yang mencapai KKM dengan nilai terendah 15 dan nilaitertinggi 65 . Hal ini dipengaruhi oleh taraf kesukaran soal. Soal yang diberikan kepada siswa memiliki taraf kesukaran dengan kategori sedang dan sukar. Soal yang diberikan kepada siswa lebih banyak dengan kategori sukar, sehingga mempengaruhi hasil belajar siswa. Meskipun demikian, hasil belajar siswa dengan menggunakan model pembelajaran berdasarkan masalah memberikan Pengaruh dengan peningkatan hasil belajar sebesar 11,4 $\%$.

Perolehan nilai rata-rata LKS kelas eksperimen pada pertemuan I sebesar 48,6, pada pertemuan II meningkat menjadi 60,4 dan pada pertemuan III meningkatmenjadi77,8. Maka dari hasil penilaian LKS yang meningkat pada setiap pertemuan memberikan Pengaruh terhadap nilai 
postes siswa kelas eksperimen, karena pada saat pengerjaan LKS siswa dilatih untuk berpikir kritis terhadap masalah di kehidupan sehari-hari yang berkaitan dengan materi listrik dinamis sehingga siswa dapat mengerjakan soal tes hasil belajar.

Penelitian yang dilakukan peneliti dengan menggunakan model pembelajaran berdasarkan masalah dalam pembelajaran cukup menarik perhatian siswa, sehingga siswa lebih antusias mengikuti pembelajaran. Penggunaan model pembelajaran berdasarkan masalah membuat siswa merasa diikutsertakan dalam pembelajaran. Siswa menjadi tahu bahwa masalah dalam kehidupan sehari-hari dapat diselesaikan dengan cara tertentu. Siswa senang karena mereka diberikan kesempatan untuk melakukan penyelidikan sendiri melalui eksperimen dimana sebelumnya sama sekali belum pernah dilakukan baik didalam kelas maupun di laboratorium. Rasa senang membuat siswa menjadi lebih aktif. Siswa aktif dalam mencari informasi, memahami materi yang dipelajari melalui buku pelajaran dan internet.

Berdasarkan data yang diperoleh tersebut ternyata hasil belajar siswa dengan menggunakan model pembelajaran berdasarkan masalah menunjukkan hasil yang cukup baik. Hal ini sejalan dengan pernyataan Rusman (2013: 75) dalam bukunya bahwa kemampuan berpikir siswa pada pembelajaran berdasarkan masalah betul-betul dioptimalisasikan melalui proses kerja kelompok atau tim yang sistematis, sehingga siswa dapat memberdayakan, mengasah, menguji, dan mengembangkan kemampuan berpikirnyasecara berkesinambungan. Dalam model pembelajaran berdasarkan masalah sebuah masalah yang dikemukakan kepada siswa harus dapat membangkitkan pemahaman siswa terhadap masalah, sebuah kesadaran akan adanya kesenjangan, pengetahuan, keinginan memecahkan masalah, dan adanya persepsi bahwa mereka mampu memecahkan masalah tersebut.

Hasil penelitian ini sesuai dengan penelitian terdahulu yaitu Suhanda (2014: 75) menyimpulkan bahwa hasil belajar fisika siswa dengan menggunakan model pembelajaran berdasarkan masalah lebih baik dari hasil belajar fisika siswa dengan menggunakan model pembelajaran konvensional. Dengan rata-rata tes hasil belajar kelas eksperimen adalah 75,13 sedangkan kelas kontrol 66,19. Setiawan (2013: 293) juga menyimpulkan bahwaada perbedaan yang signifikan hasil belajar siswa menggunakan model pembelajaran berdasarkan masalah dengan pembelajaran konvensional pada pembelajaran fisika di SMA dimana rata-rata hasil belajar siswa di kelas eksperimen yaitu 73,77sedangkan kelas kontrol yaitu 62,76. Selanjutnya, Medriati (2013: 138)dengan hasil penelitian menyimpulkan bahwa pembelajaran fisika dengan menerapkan model pembelajaran berdasarkan masalah dapat meningkatkan aktivitas dan hasil belajar siswa dengan nilai rata-rata siklus I sebesar 69,91, siklus II sebesar 80,13 dan siklus III sebesar 90,32. Rusnayati (2011: 335) menyimpulkan ada peningkatan keterampilan proses sains dengan menerapkan model pembelajaran pembelajaran berdasarkan masalah dengan pendekatan inkuiri. Pulungan (2012: 43) menyimpulkan perubahan perilaku jujur, disiplin, gigih, dan bertanggung jawab terjadi secara signifikan dikelompok siswa dengan model pembelajaran berdasarkan masalah berbasis pendidikan karakter sedangkan kelompok siswa dengan model pembelajaran berdasarkan masalah dan juga kelompok siswa dengan model pembelajaran konvensional tidak terjadi perubahan. Lelik (2011: 659) mengatakan ada perbedaan signifikan hasil belajar 
siswa di kelas ekperimen yang menggunakan model pembelajaran berdasarkan masalah dengan kelas kontrol yang diajar menggunakan pembelajaran konvensional dengan rata- rata hasil belajar di kelas kontrol yaitu 78,85 dan di kelas kontrol yaitu 64,45 .

Penggunaan model pembelajaran berdasarkan masalah pada kelas eksperimen memberikan pengaruh terhadap hasil belajar siswa tidak terlepas dari kegiatan-kegiatan yang diikuti siswa selama proses pembelajaran. Aktivitas siswa semakin meningkat sejalan dengan fase-fase pada model pembelajaran berdasarkan masalah yang memiliki lima fase yaitu, pertama orientasi siswa pada masalah. Fase pertama merupakan fase dimana guru menjelaskan tujuan pembelajaran, menjelaskan logistik yang dibutuhkan, mengajukan fenomena atau demonstrasi atau cerita untuk memunculkan masalah, memotivasi siswa untuk terlibat dalam pemecahanmasalah yang dipilih.Pada fase ini, peneliti memusatkan perhatian siswa dengan LKS. LKS tersebut menyajikan suatu masalah dimana perlu suatu solusi konkret untuk mengatasi masalah tersebut. kemudian peneliti memberikan kepada siswa pertanyaan untuk memberikan tanggapan tentang solusi terhadap masalah yang dibicarakan dimana solusi yang diberikan dapat diselidiki. Saat fase ini berjalan, hanya beberapa siswa yang antusias dalam memberikan pendapat-pendapatnya. Hal ini disebabkan karena siswa baru pertama kali belajar dengan menggunakan model pembelajaran berdasarkan masalah. Fase kedua mengorganisasi siswa untuk belajar, fase ini mengharuskan siswa untuk mendefinisikan dan mengorganisasikan tugas belajar yang berhubungan dengan masalah tersebut. Fase ini dimulai dengan pembentukan masingmasing kelompok dan membagikan LKS kepada siswa. Selanjutnya siswa dituntut mengumpulkan informasi dari berbagai sumber (internet dan buku) dan menuliskannya pada LKS poin hipotesis. Setelah setiap kelompok sudah mengumpulkan informasi yang diperlukan selanjutnya siswa bersama kelompoknya berdiskusi untuk merancangpercobaan yang akan mereka kerjakan yang dibantu oleh peneliti. Peneliti juga memberi bimbingan terhadap semua kelompok dalam menentukan jadwal pengerjaan LKS. Peneliti membimbing siswa dalam memanajemen waktu dan pembagian tugas terhadap masing-masing siswa dalam setiap kelompok, sehingga semua siswa bekerja dan memiliki tugasnya masing-masing.Pada fase ini setiap kelompok harus duduk bersama kelompoknya masing-masing, dan siswa harus mengangkat kursi dan menggeser meja membentuk kelompok, dan hal ini sangat menyita banyak waktu. Selain itu, pada fase ini peneliti harus memperkenalkan alat dan bahan terlebih dahulu kepada siswa karena siswa kurang akrab dengan alat dan bahan percobaan yang akan digunakan. Fase ketiga yaitu membimbing penyelidikan individual smaupun kelompok. Siswa pada fase ini melaksanakan percobaan yang dibimbing oleh peneliti. Berdasarkan pengamatan yang dilakukan terlihat siswa aktif dalam mengerjakan percobaan kelompoknya masingmasing. Namun masih ada beberapa kelompok yang kurang serius melakukan percobaannya. Di fase ini, sangat menyita banyak waktu karena ada beberapa kelompok yang belum bisa mengoperasikan alat percobaan yang disediakan, cara menggunakan, dan cara membaca alat tersebut. Disamping itu, keributan terjadi saat ada beberapa bahan percobaan yang rusak. Fase keempat adalah mengembangkan dan menyajikan hasil karya. Setiap kelompok mempresentasikan hasil eksperimen yang dibuat siswa dan menjelaskan manfaat dan kaitan eksperimen yang di 
buat dengan materi yang dipelajari. Tidak semua kelompok dapat mempresentasikan hasil percobaannya dikarenakan waktu terbuang untuk menertibkan siswa. Fase kelima, menganalisis dan mengevaluasi proses pemecahan masalah. Pada fase ini, siswa dibantu oleh guru untuk melakukan refleksi atau evaluasi terhadap penyelidikan mereka dan proses-proses yang mereka gunakan.Guru melakukan koreksi dan mengkaji ulang hasil jawaban masingmasing kelompok. Namun pada fase ini, peneliti hanya menyampaikan kesimpulan saja dikarenakan waktu tidak memadai.

Hasil penelitian tersebut membuktikan bahwa penerapan pembelajaran berdasarkan masalah dapat mengembangkan aktivitas belajar saintifik siswa yaitu berupa kegiatan melakukan pengamatan, bertanya, melakukan penyelidikan atau percobaan, menalar, menjalin hubungan dengan orang lain dalam upaya memperoleh informasi atau data (mengkomunikasikan). Mengamati meliputi kegiatan membaca, mendengar, menyimak dan melihat.

Berdasarkan pengamatan yang dilakukan peneliti selama proses pembelajaran berlangsung menunjukkan kemauan siswa untuk mau belajar. Pengamatan tersebut sejalan dengan kelebihan model pembelajaran berdasarkan masalah itu sendiri, yaitu bahwa dengan model pembelajaran berdasarkan masalah akan meningkatkan kemauan belajar siswa untuk belajar dan mendorong siswa untuk melakukan pekerjaan penting

Penggunaan model pembelajaran berdasarkan masalah dapat meningkatkan hasil belajar tetapi selama pembelajaran masih ada kendala yang dihadapi yaitu menentukan masalah apa yang layak dijadikan masalah yang akan dipecahkan saat proses pembelajaran berlangsung, peneliti belum mampu menyajikan masalah yang akan dipecahkan lebih spesifik. Siswa juga masih bingung dengan bentuk masalah yang diberikan oleh peneliti karena siswa tidak pernah menerima soal yang berupa masalah yang bekaitan dengan kehidupan sehari-hari karena siswa hanya terbiasa mengerjakan soal yang berupa aplikasi rumus, perencanaan kegiatan belajar mengajar dalam RPP tidak sesuai dengan kenyataan karena kurangnya waktu. Hal ini terlihat pada fase keempat saat pelaksanaan mempresentasikan hasil diskusi yang hanya bisa menampilkan dua kelompok yang seharusnya lima kelompok, siswa kurang dekat dan belum terbiasa dengan alat praktikum, membuat siswa bingung dan canggung dalam melakukan eksperimen.

\section{KESIMPULAN DAN SARAN}

Berdasarkan hasil penelitian yang diperoleh dari hasil analis data pengujian hipotesis penelitian tampak bahwa hasil belajar siswa dengan menggunakan model pembelajaran berdasarkan masalah khususnya pada materi pokok listrik dinamis memberikan nilai rata-rata dengan kategori cukup baik, menggunakan model konvensional nilai rata-rata dengan kategori kurang, sehingga dapat dikatakan bahwa ada pengaruh model pembelajaran berdasarkan masalah terhadap hasil belajar siswa pada materi pokoklistrikdinamis di kelas X Semester II SMA Negeri 13 Medan T.P 2014/2015.

Saran bagi peneliti selanjutnya diharapkan sebelum memulai proses pembelajaran terlebih dahulu dijelaskan kepada siswa bagaimana pelaksanaan model pembelajaran berdasarkan masalah, sehingga pada saat pelaksanaan pembelajaran para siswa sudah mengerti apa yang akan dilakukan dan tidak menyita waktu untuk fase-fase pembelajaran yang lain. Peneliti selanjutnya sebaiknya memperkenalkan siswa dengan alat dan bahan praktikum agar siswa tidak 
bingung dan menghabiskan banyak waktu dalam melakukan eksperimen.

\section{DAFTAR PUSTAKA}

Celik, P., (2011: 659), The effect of problem- Based Learning Student's Sucsess In Physics Course. The journal of procedia-social and behavioral science, 28 (2011), 656660.

Medriati, R., (2013), Upaya Peningkatan Hasil Belajar Fisika Siswa Pada Konsep Cahaya Kelas VII6 Melalui Penerapan Model Pembelajaran Problem Based Learning (PBL) Berbasis Laboratorium di SMPN 14 Kota Bengkulu. Jurnal Prosiding Semirata FMIPA Universitas Lampung 2013.

Ngalimun., (2014), Strategi dan Model Pembelajaran, Penerbit Aswaja Pressindo, Yogyakarta.

Pulungan, F. R., (2012), Pengaruh model pembelajaran probem Based Learning berbasis pendidikan karakter terhadap perubahan karakter dan kemampuan menyelesaikan masalah fisika, Jurnal Penelitian Inovasi Pembelajaran Fisika ISSN 20855281.

Rusman., (2013), Model-Model Pembelajaran Mengembangkan Profesionalsme Guru Edisi Kedua, PT Gravindo Persada, Jakarta.

Rusnayati, H., (2011), Penerapan model pembelajaran problem based learning dengan pendekatan inkuiri untuk meningkatkan keterampilan proses sains dan penguasaan konsep elastisitas pada siswa SMA, Jurnal Prosiding Seminar Nasional Penelitian Fakultas MIPA UNY 2011.

Sani,R. A., (2014), Pembelajaran Saintifik untuk Implementasi Kurikulum 2013, Bumi Aksara, Jakarta.

Sanjaya, W., (2010), Strategi Pembelajaran Berorientasi Standar
Proses Pendidikan, Kencana Prenada Media Group, Jakarta.

Setiawan, G. C., (2013), Penerapan model pembelajaran Problem based learning (PBL) disertai media computer makro media flash, Jurnal Pembelajaran Fisika Volume 1 Nomor 3 Desember 2012.

Suhanda., (2014), Penerapan model pembelajaran berbasis masalah dan tutor teman sebaya terhadap hasil belajar fisika kelas VII MTSN kota Solo, Jurnal Pendidikan MIPA Volume 1 Nomor 1 Januari 2014.

Trianto., (2011), Mendesain Model Pembelajaran Inovatif-Progresif, Kencana Prenada Media Group, Jakarta. 